\title{
Promulgation of RTE-Act among Disabled Children
}

\author{
Krishna Mohan $\mathrm{P}^{1 *}$, Dr. M. Ravi Babu ${ }^{2}$
}

\section{ABSTRACT}

Disability is not merely a physical fact, but also involves a normative, cultural, and legal concept. The society's perception of a disabled person also reflects its idea of a normally functional human being and the definition as considered by the society gives us an insight into the society's self image. The recognition by the society of the terms mentally and physically disabled also implies a responsibility of the society towards the people who fit that description. A society with deep ethos of social responsibility is likely to be more open in its definition of disability. The Right of Children to Free and Compulsory Education Act, 2009 is landmark legislation in the history of the Nation that makes elementary education a fundamental right for children between the ages of 6-14. But millions of children with disabilities got left out in the Act. Being a Challenged Person i would like to extent to knowledge about educational and psychological well being of disabled children's. In my point of view there are many challenges and issues are not implementing properly the challenges like lack of awareness, not involving the teachers directly, there is no implementation in lower level educational systems, there is any reviews of the act at least yearly once. Etc. This paper highlights some of the challenges that are faced by children with disabilities in achieving their right to education. If we can implement all above issues related challenges all most maximum numbers of disabled children are benefit in future. This paper also disseminates knowledge by giving suggestions for effective implementation of RTE for the children with disabilities.

Keywords: Persons with Disabilities, Right to Education, Human Rights.

Right to education can indeed provide a ripe platform to reach the unreached persons with disabilities, if specific provisions are given to them. Despite the rising enrolments, disabled persons still miss out disproportionately on receiving any kind of education and have to face many challenges. Sarva Shiksha Abhiyaan (SSA) talks of Education for all but the fact remains that many disabled children are not enrolled under this scheme due to their severity of disability. For the first time, the right to education of disabled children was given special focus with the

\footnotetext{
${ }_{1}^{1}$ Junior Research Fellow, Faculty of Education, Osmania University, Hyderabad

${ }^{2}$ M.A (Psy), M.Ed., Ph.D, Faculty, Telangana State Model School

*Responding Author

(C) 2016 I K Mohan, R Babu; licensee IJIP. This is an Open Access Research distributed under the terms of the Creative Commons Attribution License (http://creativecommons.org/licenses/by/2.0), which permits unrestricted use, distribution, and reproduction in any Medium, provided the original work is properly cited.
} 


\section{Promulgation of RTE-Act among Disabled Children}

passing of the Persons with Disabilities (PWD) Act. The RTE Act has not mentioned about children with disabilities. By acknowledging and promoting the equal rights of disabled children to education we can bring a change. Taking disabled children' rights seriously requires strong and immediate action.

Education is both a human right in itself and an indispensable means of realizing other human rights. It enables children and young people to develop a sense of their own worth and respect for others. In doing so, it fosters their ability to contribute to and participate fully in their communities. Education is the primary vehicle by which economically and socially marginalized children and young people can eventually lift themselves out of poverty, through developing the skills and qualifications necessary for quality paid work

The Right of Children to Free and Compulsory Education Act, 2009 is landmark legislation in the history of the Nation that makes elementary education a fundamental right for children between the ages of 6-14. But millions of children with disabilities got left out in the Act. Amendments to this law are due to be presented to the Parliament in a supposed attempt to correct this huge oversight. But rather than taking a progressive step towards inclusion, the proposed Amendments seem to be itching towards legalizing exclusion of children with severe and profound disabilities.

In 2002, elementary education was made a fundamental right in our country. The right to free and compulsory education for children between the ages of 6 to 14 is a fundamental right inscribed under Article 21 (A) of the Constitution of India which says, "The States shall provide free and compulsory education to all children of the age of six to fourteen (6-14) years in the manner as the State may by Law, determine.”

In 2009, the Government of India passed the Right of Children to Free and Compulsory Education Act, 2009 or the R.T.E. Act. This is the Act that translates the vision of the fundamental right to education into reality. The R.T.E. Act did not include children with disabilities specifically in the disadvantaged groups, even though national studies show that children with disabilities are the largest group of out of school children. It is also well known that children with disabilities are over represented amongst the poorest of the poor in any country.

The Right of Children to Free and Compulsory Education Act, 2009 is landmark legislation in the history of the Nation that makes elementary education a fundamental right for children between the ages of 6-14. But millions of children with disabilities got left out in the Act. Amendments to this law are due to be presented to the Parliament in a supposed attempt to correct this huge oversight. But rather than taking a progressive step towards inclusion, the proposed Amendments seem to be itching towards legalizing exclusion of children with severe and profound disabilities. Children with disabilities, including children with very high support needs, are equal holders of this fundamental right. Yet today, through the proposed Amendments 


\section{Promulgation of RTE-Act among Disabled Children}

to the Right to Education (R.T.E.) Act, 2009, this fundamental right of the child is being watered down and instead of a school, home is being offered as a legitimate, alternative option for the education of a child with high support needs.

\section{Who are the disabled children that can benefit from the Act?}

While the original RTE Act passed in April 1, 2010 specifically mentions children with disability, the Amendment passed in 2012 resulted in an expanded definition of children with disability and other enabling measures. This broader definition now includes:

- A child with disability is to be included in the Act's definition of children belonging to a 'disadvantaged group'.

- A child with 'disability' as defined in 1995 Persons with Disabilities Act

- A child with 'disability' and 'severe disability' as defined in National Trust for Welfare of Persons with Autism, Cerebral Palsy, Mental Retardation and Multiple Disabilities Act, 1999.

\section{International human rights framework}

The human right of all children to education has been recognised since the Universal Declaration of Human Rights (UDHR, Article 26) in 1948, and has been articulated in a range of international conventions, including the International Covenant on Economic, Social And Cultural Rights (ICESCR, 1966) and the Convention on the Rights of the Child (CRC, 1989).

The right to education is outlined in the Convention on the Rights of the Child, in articles 28 and 29. Article 23 recognises children with physical or mental disabilities are entitled to enjoy a "full and decent life" in conditions that ensure dignity, promote self-reliance and facilitate the child's active participation in the community. The Committee on the Rights of the Child's General Comment No.9 on the rights of children with disabilities specifically adopts inclusive education as the goal for educating disabled students.

Education (Salamanca Statement) - The statement sets out four assumptions that form the basis of the inclusive education philosophy:

- All students come to school with diverse needs and abilities, so no students are fundamentally different

- It is the responsibility of the general education system to be responsive to all students

- A responsive education system provides high expectations and standards, a quality curriculum and instruction, an accessible environment and teachers who are well prepared to address the educational needs of all students

- Progress in general education is a process evidenced by schools and communities working together to create citizens for an inclusive society.

The UN Convention on the Rights of Persons with Disabilities was adopted by the UN General Assembly on 13 December 2006. Article 7 affirms disabled children are entitled to the entire 


\section{Promulgation of RTE-Act among Disabled Children}

range of human rights inherent to all children. Their right to appropriate support in making their voices heard is emphasised in both articles 7 and 24. Article 24 also recognises:

- A clear commitment to the principle of inclusive education

- The specific needs of children with severe and complex sensory impairments who require learning supports such as sign language, Braille and low vision aids

- Disabled children require support that is individually tailored and resourced (both in terms of time and staffing) and decided in partnership with them and their parents.

- Modifications to the curriculum, styles of teaching and classroom organisation may be necessary.

\section{Right to Education Act and Disabled Children:}

- Right to elementary education becomes the fundamental right of each and every child including 8-10 percent disabled children u/s 3(1) of Right to Education (RTE) Act 2009 and u/s 2(i) of the Person with Disability (PWD) Act, 1996.

- Section 3(1) envisages that 'Every child of age 6-14 years shall have a right to free and compulsory education in a neighbourhood school till completion of elementary education'.

- Provided that a child suffering from disability, as defined in section 2(i) of the PWD Act,1996, shall have right to pursue free and compulsory elementary education in accordance with the provisions of Chapter $\mathrm{V}$ of the said Act.

- Among the age group of 6-14, there are 8-10 percent those children who are suffering from disability shall also have right to pursue free and compulsory elementary education in accordance with the provisions of the said act.

- Apart from normal children, one of its prime objectives is to include the excluded children with special need (CWSN) in the mainstream schools and educate them without any discrimination.

- Inclusion is not an experiment to be tested but a value to be followed. All the children whether they are disabled or not have the right to education as they are the future citizens of the country.

\section{KEY ENTITLEMENTS AND COMMITMENTS UNDER THE PWD ACT, 1995}

The PWD Act has both binding entitlements and more general commitments. The key provisions are:

Education: The following are binding on Government (i.e. not subject to economic factors):

- Governments shall ensure that every CWD has access to free education "in an appropriate

- Environment" until the age of eighteen.

- Governments "shall initiate or cause to be initiated" research by public and nongovernmental agencies for development of both assistive devices and special learning materials for CWD in order to promote equal opportunity in education.

- Governments shall ensure teacher training that produces "the requisite manpower" for teaching of CWD both in special schools and integrated settings.

- All public educational institutions and other receiving aid from Government shall reserved not less than 3 percent of seats for PWD (i.e. for PWD over 18 years). 


\section{Promulgation of RTE-Act among Disabled Children}

- Government should prepare a "comprehensive education scheme” for CWD which includes transport or financial incentives, barrier free access, supply of book, uniforms and learning materials to CWD, adjusts the examination system as necessary, adapts curriculum for CWD.

Prevention and early detection of disabilities: All commitments in this area are given with the provisions "within the limits of their economic capacity and development”.

With provisons, Governments should:

- Undertake surveys on causes of disability.

- Promote "various methods" for preventing disabilities.

- Screen children at least once a year for identifying at-risk cases.

- Provide facilities for training PHC staff.

- Conduct or sponsor awareness campaigns on hygiene, health and sanitation, and on causes and prevention of disabilities.

- “take measures” for pre-, peri- and post-natal care of mother and child.

\section{Challenges of Right to Education of Disabled Children:}

1. Pre-schooling of Disabled Children

2. Issue of Equality and Equity of RTE

3. Discrimination in School

4. Quality of Special Teachers

5. Violation of RTE Act

\section{Challenges need to be addressed:}

Pre-Schooling: 0 to 6 years of the CWSN are excluded from the ambit of the RTE Act-2009 Equality and Equity of RTE:

- Do the disabled have the same right to education as those who are not disabled?

- Do they are equally treated in classroom?

- Do they given equal opportunities to educate in mainstream schools?

\section{Discrimination in Schools:}

- Teachers and peers are discriminating CWSN

- Due to lack of sensitivity the teachers began to fell problem in overall looking after such children

\section{Quality of Resource Teachers:}

- A person possessing B.Ed. (SE) degree recognized by RCI may be appointed as elementary teachers.

- But candidate has to qualify in TET conducted by central government or state government.

\section{Financial Crunch over Education of CWSN:}

- Act has no genuine concern for financial allocation required to ensure RTE 


\section{Promulgation of RTE-Act among Disabled Children}

Estimates for the additional resources required to achieve the goal of universal elementary education currently range from 0.8 per cent to 2.5 per cent of GDP

\section{Violation of RTE:}

- There are not any provisions for action against government authorities, in case of any negligence in implementation of Right to Education.

\section{DISCUSSION}

In India the development of right to education has undergone an eventful journey, when the Constitution was enacted education was kept in the Part IV of the Constitution, as Directive Principles of State Policy, wherein Article 41 provides rights to work, to education, and to public assistance in certain cases. Article 45 makes provision for free and compulsory education. Article 46 provides the promotion of educational and economic interests of scheduled castes, scheduled tribes and other weaker sections. Education is a two way concept, it is the state's obligation to provide education by way of the Directive Principles of State Policy, and it is also guaranteed as a fundamental right in Part IV of the Indian Constitution. Having more options is always better. The education bill aims to provide free education to children with severe disabilities, which is a welcome move as long as it is implemented properly. With the Right to Education (RTE), there are more options available today to children belonging to different backgrounds to receive quality education than before. For those suffering with severe disabilities, the right to receive home-based education is a reforming idea.

\section{CONCLUSION}

The need of the hour is that there should be various options available whether children are special or normal. When the RTE Act is implemented, we must see that the schools meet the required standards. It is true that inclusion is going to require a systemic change. We need changes in curriculum and the ways in which we transact this curriculum, teacher training and flexibility in administration. R.T.E. tells us how the fundamental right to education will be implemented in our country. We have seen that it has been able to make fundamental systemic changes in the education scenario of our country. By acknowledging and promoting the equal rights of disabled children to education we can bring a change. Taking disabled children' rights seriously requires strong and immediate action. If we can implement all above issues, all most maximum numbers of disabled children may be benefited in the future.

\section{REFERENCES}

Aggarwal, R. (1994). India. In K. Mazurck \& M. A. Winzer (Eds.), Comparative studies in special education (pp. 179-203). Washington D. C.: Gallaudet University Press.

Alur, M. (2001). Inclusion in the Indian Context. Humanscape, 8(6), 1-8.

Azad, Y. A. (1996). Integration of disabled in common schools: A survey-study of IEDC in the country. New Delhi: National Council of Educational Research and Training. 


\section{Promulgation of RTE-Act among Disabled Children}

Baquer, A., \& Sharma, A. (1997). Disability: Challenges vs responses. New Delhi: Concerned Action Now.

Canadian International Development Agency (CIDA). (2003). India Country Program Framework (2002-2007). Retrieved 10th June, 2003, from www.acdi-cida.gc.ca

Chatterjee, G. (2003, April). The global movement for inclusive education. Retrieved 10th July, 2003, from http://www.indiatogether.org/2003/apr/edu-inclusive.htm

Das, A. K., \& Pillay, A. N. (1999, December). Inclusive education for disabled students: Challenges for teacher education. Paper presented at the 5th UNESCO-ACEID Conference, Bangkok, Thailand.

Jangira, N. K. (1995). Rethinking teacher education. Prospects, 25(2), 261-272.

Mani, R. (1988). Physically handicapped in India. Delhi: Ashish Publishing House.

Mastropieri, M. A., \& Scruggs, T. E. (2004). The inclusive classroom: Strategies for effective instruction. NY: Pearson.

Miles, M. (1995). Disability in an eastern religious context: Historical perspectives. Disability and Society, 10(1), 49-69.

Miles, M. (1997). Disabled learners in South Asia: lessons from the past for educational exporters. International Journal of Disability, Development and Education, 44(2), 97104.

Miles, M. (2000). Disability in South Asia- Millennium to millennium. Asia Pacific Disability Rehabilitation Journal, 11(1), 1-10. 